\title{
The Impact of Exchange Rate Uncertainty on Exports in South Africa
}

\author{
Goodness C. Aye ${ }^{1}$ \\ Department of Economics, University of Pretoria \\ Rangan Gupta \\ Department of Economics, University of Pretoria \\ Prudence S. Moyo \\ Department of Economics, University of Pretoria \\ Nehrunaman Pillay \\ Department of Economics, University of Pretoria
}

\begin{abstract}
This paper examines the impact of real effective exchange rate uncertainty on aggregate exports of South Africa for the period 1986Q4-2013Q2. Using a bivariate framework where the structural vector autoregression is modified to accommodate bivariate GARCH-in-Mean errors, we find that exchange rate uncertainty has a significant and negative effect on exports. Comparing the response of exports to a shock in exchange rate from a model that includes the real effective exchange rate uncertainty with results from a model that restricts the coefficient of the exchange rate uncertainty to zero, we find that the response is more pronounced in the former model. Furthermore, real exports respond asymmetrically to negative and positive shocks to real effective exchange rate shocks of the same size.
\end{abstract}

JEL Codes: C32, E32, F1

Keywords: Exchange Rate Uncertainty, Real Effective Exchange Rate, Exports, Bivariate GARCH-in-Mean VAR

\footnotetext{
${ }^{1}$ Goodness C. Aye, Department of Economics, University of Pretoria, 0002, Pretoria, South Africa, Email: goodness.aye@gmail.com
} 


\section{Introduction}

The disintegration of the Bretton Woods system of fixed exchange rates in the early 1970s gave rise to several theoretical and empirical studies aimed at understanding the relationship and impact of exchange rate uncertainty on trade. To this day, the paradox as to the impact of exchange rate uncertainty on trade flows remains. The objective of this study is to reinvestigate the exchange rate uncertainty-export relationship for South Africa.

The early aftermath of the breakdown of the Bretton Woods system saw South Africa initially opting to peg its exchange rate to the US dollar in the latter part of 1971. By June 1972, the rand was pegged to the pound sterling and four months later, the rand was again linked to the US dollar. Since June 1974, the South African authorities have allowed the rand to be an independent managed float (Van der Merwe, 1996).

The past two decades have seen South Africa integrate more fully with the global economy. As an emerging economy with a liquid and well established foreign exchange market, South Africa's currency has also been vulnerable to booms and busts in capital flows. This is evidenced in the frequent but short periods of appreciations and depreciations of the rand against other currencies. More recently, the Governor of the South African Reserve Bank (SARB) noted in the Monetary Policy Statement of September 2013 that the 'exchange rate has been highly volatile since the previous meeting' (South African Reserve Bank, 2013). This volatility has over the past decade been one of the key items of public debate (Isa, 2009; Luus, 2010; Gross and Maylie, 2011; Fuchs and Torchia, 2011 and McGroarty, 2013).

The need to examine the relationship between exchange rate volatility and exports cannot be overemphasized. As neatly captured in theory developed by Clark (1973) and Ethier (1973), the most important impact of volatility on the exchange rate is the consequent excessive swings in national output, employment and productivity. A risk-averse firm is concerned about the risks to its operational costs and profits as measured in local currency. Such a firm will 
want to reduce its risk exposure as greater exchange rate uncertainty reduces expected profits and thereby viability of the business concern.

Further justification of a study of this nature can be made by considering an extract from Héricourt and Poncet (2012, p.10): "When facing a real depreciation of its own currency, the current earnings of a firm rise. The firm may use this additional income to fund the sunk costs of entering new markets. But once these investments are made, it will be very difficult, and most of the time impossible, to back out and recover the cost of those investments even in the case of an abrupt subsequent currency appreciation. If firms are credit constrained, they will face additional difficulties to fund new investments, and will be even more reluctant to take the chance of engaging in exports to markets characterised by highly volatile exchange rate." Overall, increased volatility in the real exchange rate hurts the economy through its adverse consequences on private agents' consumption and investment decisions. The exchange rate risk increases transaction costs and reduces the gains to international trade (Héricourt and Poncet, 2013).

Previous investigations of exchange rate uncertainty on exports in South Africa have produced conflicting results similar to that obtained from studies in other countries as will be evident from our discussion below. The conflicting results could be partly attributed to methodological flaws of using the two step procedure whereby exchange rate volatility is first generated from a univariate $\mathrm{ARCH}$ or GARCH model and then its relationship with exports is examined using other econometric models. This procedure leads to generated regressor problem (Pagan, 1994). Therefore, the current study intends to contribute to the existing literature by using a more efficient method (GARCH-in-Mean) that avoids the generated regressor problem by simultaneously estimating all the parameters by the full information maximum likelihood .

Excessive exchange rate volatility may be thought of as a situation where the currency moves too much, i.e. that exchange rate volatility is greater than is warranted by movements in 
economic fundamentals (Pétursson, 2009). In practice, as noted by Bird and Rajan (2001) and Rajan $(2002,2004)$, it is difficult to define or measure what excessive exchange rate volatility is. Our measure of exchange rate volatility is the standard deviation of the one-step-ahead forecast error of the growth rate of real effective exchange rate (REER), conditional on the contemporaneous information set.

More precisely, we use a bivariate framework where the structural vector autoregression is modified to accommodate bivariate GARCH-in-Mean (GARCH-M) errors to investigate the impact of exchange rate uncertainty on aggregate exports of South Africa for the period 1986Q4-2013Q2. The GARCH-M model is a more efficient technique for estimating time varying volatility and its effect on exports compared to other approaches used on South African data. Moreover, we also contribute by considering the asymmetric effect of exchange rate volatility on South Africa's exports which has not been considered in the past to the best of our knowledge. The asymmetry implies that exchange rate volatility affects exports differently during appreciations and depreciations, may arise from a number of sources such as exporter asymmetric risk perception, US-dollar invoicing, original sin, fear of floating, fear of appreciation, love of depreciation, lack of active or improper foreign exchange market intervention among others (Fang et al. 2009). Further, our study uses a more recent and longer sample (1986Q4-2013Q2) compared to the previous studies. The longer sample not only helps us to track the historical changes in exports due to exchange rate volatility but also its dynamics during and after the recent global financial crisis.

The remainder of the paper is structured as follows. Section 2 provides a review of some of the empirical literature on the impact of exchange rate uncertainty on exports. Section 3 describes the empirical model used to assess the impact of exchange rate uncertainty on exports. Section 4 describes the data. Section 5 presents and discusses the empirical results. Section 6 concludes the paper. 


\section{Literature Review}

The theoretical literature to explain the relationship between exchange rate volatility and exports is ambiguous, depending on the underlying assumptions (Clarke, 1973; Ethier 1973; Franke, 1991 among others) A number of empirical studies have also been conducted on the relationship between exchange rate volatility and trade (Caballero and Corbo, 1989; Asseery and Peel, 1991; Kroner and Lastrapes, 1993; De Arcangelis and Pensa, 1997; Rahman and Serletis, 2009; Zakaria, 2013 among others). Similar to the theoretical literature, the empirical results are often mixed depending on the measure of exchange rate volatility used; the time dimension of exchange rate volatility, i.e. short or long-run measure; the choice between real and nominal exchange rate; the nature of trade flows; the sample period and countries included and the estimation technique employed. ${ }^{2}$

As far as South Africa is concerned, some studies have been conducted on exchange rate volatility and trade. Todani and Munyama (2005) using seasonally adjusted quarterly data for the period 1980 to 2004 investigate the effect of nominal effective, real effective and randdollar exchange rate volatility on real aggregated and disaggregated exports in South Africa by specifying an exports demand equation as a function of relative prices, foreign income and exchange rate volatility. They determine their exchange rate volatility measure using both ARCH and GARCH models and the moving average standard deviation and then include each as a regressor in an ARDL bound testing procedure. They find that depending on the measure of volatility used, either there is no significant relationship between South African export flows and exchange rate volatility or when such relationship is significant, it is positive. This finding is attributed to the consequence of the open nature of the South African economy, or that exporters are aware of the limitations of the domestic market to absorb excess supply of goods

\footnotetext{
2 Clark et al. (2004) explore exchange rate volatility along several dimensions, type of exchange rate volatility, by country group and by type of trade. Also McKenzie (1999), Cote' (1994), Hodge (2005) and Ozturk (2006) provide a comprehensive survey of a number of research studies that have incorporated some or all of these key issues in their empirical studies and the consequent results.
} 
that may arise during periods of high exchange rate volatility and consequently export more to avoid reduction in revenues. They also attribute the statistically insignificant relationship between exchange rate volatility and exports to the availability of hedging facilities in South Africa.

Schaling (2007) analyses the relationship between exchange rates, inflation and competitiveness in South Africa over the period 1994 to 2006. Employing the Johansen Vector Error Correction Model (VECM) estimation framework and using the long-term price elasticity of the demand for both imports and exports, the paper finds that the standard Marshall-Lerner condition is not satisfied. He finds a weak relationship between real effective exchange rate (REER) and export volumes and attributes this to exporter's pricing to market (PTM).

Sekantsi (2011) using monthly data, investigates the impact of real exchange rate volatility on South Africa's real aggregate and goods exports to the US in value terms during the period 1995:1-2007:2. The paper tests for the existence of cointegration and estimate longrun coefficients using the ADRL bounds testing procedure. Using a GARCH $(1,1)$ model, the exchange rate volatility is measured as the conditional variance of the first difference of the logarithm of real exchange rate. The results show a significant negative coefficient effect of real exchange rate volatility on both aggregate and goods exports. An inference drawn from this result is that South Africa exporters are risk averse and will reduce exports under conditions of high exchange rate uncertainty.

Wesseh and Niu (2012) also using ADRL bounds testing procedure for cointegration, investigate the impact of nominal and real exchange rate volatility of South African exports to China using monthly and quarterly data for the period 1992:1-2010:7 and 1995:1-2010:3, respectively. They find that when using aggregated data, South African exports to China are unaffected by short term exchange rate volatility. However at a disaggregated level, the results are ambiguous with some sectors being positively and significantly affected by exchange rate uncertainty while others are affected positively and significantly. 
Nyahokwe and Ncwadi (2013) used monthly data for the period 2000-2010 to examine the impact of exchange rate volatility on aggregate South African exports. Using the Johansen cointegration technique and VECM estimation, they found that the exchange rate has an ambiguous (positive effect in the first month and negative effect in the second month) but insignificant effect on exports, yet they propose a Tobin tax as a policy measure on foreign exchange transactions to reduce exchange rate volatility.

Overall, studies on South Africa are inconclusive as to the impact of exchange rate volatility on exports. Consequently this paper makes a further attempt to provide evidence of the relationship between exchange rate uncertainty and exports in South Africa. Most previous studies have used ARDL bounds testing procedure or a Johansen cointegration technique, whereby they first generate exchange rate volatility either by taking the moving average standard deviation of the exchange rate series or using a univariate ARCH or GARCH model to extract the volatility of exchange rate. In other words, these studies used the two-step procedure.

In this study, however, we use a bivariate GARCH-in-Mean VAR which allows us to simultaneously estimate all the parameters by full information maximum likelihood (FIML), and thus avoids the generated regressor problems associated with estimating the variance function parameters separately from the conditional mean parameters (Pagan, 1994). Further, we investigate the asymmetric effect of exchange rate volatility which was not considered in the previous studies. Our methodology is similar to that used by Rahman and Serletis (2009) who examine the effect of exchange rate uncertainty on exports using monthly data for the US over the period 1973:1 to $2007: 1$ and find that exchange rate uncertainty has a negative and significant effect on US exports and that exports respond asymmetrically to positive and negative exchange rate shocks of equal magnitude. However, we use a more recent data which includes both the pre- and post- global financial crisis than Rahman and Serletis (2009). 


\section{The Empirical Model}

This paper looks at the GARCH-M model which is an extension of Sims (1980) and Bernanke (1986)'s structural VARs. It incorporates the concept of asymmetric volatility discussed in Engle and $\mathrm{Ng}$ (1993) and the use of propositions of Engle and Kroner, (1995) discussed in Elder (1995 and 2004).

Following Elder, (1995 and 2004) (see also Rahman and Serletis, 2009), we present the dynamics of the structural VAR to represent the interrelations of South African REER volatility and changes in exports in the structural system. This representation ensures that the conditional mean of exports is dependent on the conditional standard deviation of real exchange rate shown as:

$$
\mathbf{B} \mathrm{y}_{\mathrm{t}}=\mathrm{C}+\Gamma_{1} \mathrm{y}_{\mathrm{t}-1}+\Gamma_{2} \mathrm{y}_{\mathrm{t}-2}+. .+\Gamma_{\mathrm{P}} \mathrm{y}_{\mathrm{t}-\mathrm{p}}+\left(\Lambda(0) \mathrm{L}^{0}+\Lambda(1) \mathrm{L}^{1}+\Lambda(2) \mathrm{L}^{2}+. .+\Lambda(\mathrm{p}) \mathrm{L}^{\mathrm{p}}\right) \sqrt{\mathrm{H}_{\mathrm{t}}}+
$$

$\varepsilon_{\mathrm{t}}$

where $\operatorname{dim}(\mathbf{B})=\operatorname{Dim}\left(\Gamma_{\mathrm{i}}\right)$ are $\mathrm{p} \times \mathrm{p}$ matrices, $\mathrm{y}_{\mathrm{t}}$ is a vector containing REER and real exports growth rates, $\varepsilon_{\mathrm{t}} \| \Pi_{\mathrm{t}-1} \sim \mathrm{iid}\left(0, \mathrm{H}_{\mathrm{t}}\right)$ represents uncorrelated structural disturbances in the system where $\Pi_{t-1}$ is the available information set at time $t-1$. The measure of real exchange rate uncertainty which affects exports growth contemporaneously through the matrix $\Lambda(\mathrm{L})=$ $\left(\Lambda(0) \mathrm{L}^{0}+\Lambda(1) \mathrm{L}^{1}+\Lambda(2) \mathrm{L}^{2}+. .+\Lambda(\mathrm{p}) \mathrm{L}^{\mathrm{p}}\right)$ is denoted by $\sqrt{\mathrm{H}_{\mathrm{t}}}$. In this research, we suspect that REER uncertainty negatively affects exports and hence we assume that REER will have a negative coefficient.

The term $\varepsilon_{\mathrm{t}}$ represents a homoscedastic vector of structural disturbances with respect to the information set formed exclusively from previous values of $\mathrm{y}_{\mathrm{t}}$. The representation of the conditional variance - covariance matrix $\mathrm{H}_{\mathrm{t} \in(\text { reer,exp) }}$ is guaranteed to be positive through the enforcement of suggestions by Engle and Kroner (1995) and Bredin et al. (2010). Moreover, 
$\mathrm{H}_{\mathrm{t}}$ is assumed to have structural errors that are contemporaneously correlated i.e. $\mathrm{H}_{\mathrm{t}}$ is a diagonal according to the description of VAR systems (Sims, 1980). In order to capture the phenomenon of volatility clustering (Engle, 1982), we allow $\mathrm{H}_{\mathrm{t}}$ to follow a parsimonious multivariate Generalised Autoregressive Conditional Heteroscedastic (GARCH) process. ${ }^{3}$

Further the specification of GARCH volatilities are represented according to Engle and Kroner (1995) also used in Elder and Serletis (2010) among others, we represent $h_{t}$ as follows:

$\mathrm{h}_{\mathrm{t}}=\operatorname{Diag} \mathrm{H}_{\mathrm{t}}=\mathrm{C}_{v}+\sum_{\mathrm{k}=1}^{\mathrm{r}} \mathrm{F}_{\mathrm{i}}\left(\varepsilon_{\mathrm{t}-\mathrm{k},} \varepsilon_{\mathrm{t}-\mathrm{k}}^{\prime}\right)+\sum_{\ell=1}^{\mathrm{s}} \mathrm{G}_{\mathrm{i}} \mathrm{h}_{\mathrm{t}-\mathrm{j}}$

where $C_{v}$ is a $n^{2} \times 1$ matrix, while $F$ and $G$ are $n^{2} \times n^{2}$ matrices and $h_{t}=\operatorname{vec}\left(H_{t}\right)$. The second and third terms on the RHS of equation (2) represents the ARCH and GARCH, terms respectively. The total number of parameters to be estimated in equation (1) and (2) is given by $1 / 2 n(n+1)\left(n^{2}+n+1\right)$ with distinct variance parameters for $k=\ell=1$ (Hansen and Lunde, 2005).

We also impose an identifying procedure in VARs which allows for the estimation of $\mathrm{n} *(\mathrm{n}-1) / 2$, free parameters in $\mathrm{B}$, subject to a rank condition (Elder, 2004). In estimating the bivariate GARCH in the mean-VAR model, we follow Elder (2004) and Hamilton (1994) and estimate the model parameters using the Full Maximum Likelihood methodology discussed by Elder (2004) and Elder and Serletis (2010) and Lee et al. (1995).

\section{Data}

We use seasonally adjusted quarterly data on the REER and total exports of goods and services over the period 1986Q2 to 2013Q2 sourced from the SARB. We transform the data by using the logarithmic first differences of the variables (growth rates) to achieve stationarity.

\footnotetext{
${ }^{3}$ See Engle (1982), Bollerslev et al. (1994), Bollerslev (1986) and Taylor (1987) for more details on these processes.
} 
Our measure of exchange rate uncertainty is the standard deviation of the one-step-ahead forecast error of the growth rate of REER, conditional on the contemporaneous information set. This measure of uncertainty is consistent with Rahman and Serletis (2009) and Elder and Serletis (2010).

Observation of the data indicated that in the period 1984 to 1986 there were sharp movements in the REER, attributable to the political and economic developments in South Africa. During this time, a short-term debt moratorium was declared, coupled with the imposition of financial sanctions, exchange controls on capital transfers by non-residents and the then State Presidents Rubicon Speech which exacerbated the unfavourable economic position of South Africa. The data prior to 1986Q4 was excluded from the sample as the severe exchange rate movements were likely a reaction to non-fundamentals and inclusion of this data period would distort the results. Figures 1 and 2 below show a time series plot of the variables used in our research.

We observe from Figures 1 and 2 that recession in South Africa in the 1990-1991 had little impact on volatility in REER growth but a considerable impact on South African exports. Further, the recession in 2008-2009 had a significant impact on the growth of both REER and exports.

\section{Empirical Results}

We analyse the quarterly effect of REER uncertainty on exports including 5 lags suggested by the Akaike Information criterion (AIC) and the Final Prediction Error (FPE) in the $\Lambda(\mathrm{L})$ matrix and the conditional variance term in the GARCH-M model.

The fitting of a GARCH $(1,1)$-in-Mean VAR model to data is a two stage process that begins by estimating the multivariate homoskedastic VAR to obtain the initial values of the model. The initial values are then used to estimate the GARCH $(1,1)$-in-Mean VAR, recursively. We then test the suitability of the GARCH $(1,1)$-in-Mean VAR model on capturing 
the features of the research data and compare the results with the traditionally parsimonious homoskedastic VAR through the use of the Schwarz Information Criterion (SIC) statistics. The Schwarz criterion includes a substantive penalty for the additional parameters required to estimate GARCH models, and so an improvement in the Schwarz criterion suggests strong evidence in favour of the bivariate GARCH $(1,1)$-in-Mean VAR specification (Elder and Serletis, 2010).

According to Table 1, the Schwarz criterion values indicate that our bivariate GARCHin-mean VAR captures the important features of our research data better than the traditional homoskedastic VAR since the SIC statistic is lower for our specification. We test the model performance by setting restrictions in $\mathrm{ARCH}(\mathrm{F}=0)$ and $\mathrm{GARCH}-\mathrm{in}-\mathrm{Mean}(\mathrm{F}=\mathrm{G}=\Lambda=0)$ terms against an alternative hypothesis for the two models. The results for this test are presented in Table 2. We reject the null hypothesis and conclude that coefficients of $\mathrm{F}, \mathrm{G}$ and $\Lambda$ exist. The conditional variances, $\mathrm{H}_{\text {reer }}(\mathrm{t})$ and $\mathrm{H}_{\exp }(\mathrm{t})$ are obtained from the representation in the system of equations (3) as shown below:

$$
\left[\begin{array}{c}
\mathrm{H}_{\text {reer }}(\mathrm{t}) \\
\mathrm{H}_{\exp }(\mathrm{t})
\end{array}\right]=\left[\begin{array}{l}
\mathrm{C}_{1} \\
\mathrm{C}_{2}
\end{array}\right]+\left[\begin{array}{c}
\mathrm{F}_{1} \varepsilon_{\text {reer }}(t-1)^{2} \\
\mathrm{~F}_{2} \varepsilon_{\exp }(t-1)^{2}
\end{array}\right]+\left[\begin{array}{l}
\mathrm{G}_{1} \mathrm{H}_{\text {reer }}(\mathrm{t}-1) \\
\mathrm{G}_{2} \mathrm{H}_{\exp }(\mathrm{t}-1)
\end{array}\right]
$$

The results in table 2 are plausible and support the rejection of the null hypothesis of no $\mathrm{ARCH}(\mathrm{F}=0)$ and GARCH-M $(\mathrm{F}=\mathrm{G}=\Lambda=0)$ terms. Further, it is interesting to note that $\mathrm{H}_{\text {reer }}(\mathrm{t}-1)=0$, which validates our assumption about its non-negativity requirement.

Our measure of REER uncertainty is given by $\left[\mathrm{h}_{\text {reer }}(\mathrm{t})\right]^{1 / 2}$ following a representation discussed in Elders (2004) in our research. We find that an increase in REER uncertainty leads to a massive negative impact (-0.58 percent) on South African exports and has a p- statistic of 0.0048 and a t-statistic of (-2.81) which are both statistically significant. We therefore reject the null hypothesis that the REER uncertainty in our model is zero and accept the alternative 
hypothesis that it is non-zero at the 5 percent level. Therefore, we conclude that exchange rate volatility has a negative and statistically significant effect on South Africa's exports.

The dynamic responses of exports to negative and positive shocks on exchange rate volatility are shown in Figure 3. The impulse responses are based on an exchange rate shock equal to the annualised unconditional standard deviation of the change in REER. We also report the one-standard deviation error bands (shown in dashed lines).

The results in Figure 3 indicate that a positive shock to REER leads to a negative, significant and somewhat persistent response on South African real exports. We find a massive decline in annualised growth rate of real exports by about 100 basis points after a quarter following a positive shock to real exchange rate volatility. A negative REER shock also leads to a decline in annualised growth rate of real exports by 50 basis points over a period of 3 quarters. However, this response is not statistically significant and dies off after 10 quarters.

Our results indicate that the responses of South African exports following negative and positive exchange rate uncertainty shocks are asymmetric. Asymmetry may be viewed from both the direction and magnitude of the response of export to a positive and negative exchange rate uncertainty shocks. In terms of the magnitude, the response of exports to positive exchange rate uncertainty shock is larger in absolute terms than its response to a negative exchange rate uncertainty shock (Figure 3). Moreover, in terms of direction, the response to a negative uncertainty shock is not a mirror-image (i.e not in opposing or reverse direction) of the response to a positive shock as is the case with symmetric or mirror- image effect. Hence, we conclude the exchange rate responses to the two shocks are asymmetric This may reflect South African exporters' asymmetric risk perception and hedging behaviour. Under asymmetric foreign exchange exposure, a firm's symmetric benefit-loss structure would not allow the firm to effectively manage its foreign exchange rate risk since the hedging tools have symmetric benefit-loss structures in general (Bae and Kwon, 2013). We then allowed for lagged exchange rate uncertainty to be contemporaneously related to changes in exports and compared the result 
to a model which excludes the exchange rate uncertainty. We find an amplification of the response of exports after a positive or negative shock in exchange rate with the exchange rate uncertainty coefficient unrestricted than when the coefficient is restricted as shown in Figure 4.

The negative impact of real effective exchange rate volatility on exports in South Africa indicates that firms in South Africa may be risk averse in line with the theoretical exposition of Clark (1973) which assumes that variability of the exchange rate is a measure of the risk to the trading firms and also consistent with some of the South African studies (Sekantsi, 2011; Nyahokwe and Ncwadi, 2013). An increase in exchange rate volatility would raise the cost for risk-averse traders. Consequently, these risk averse firms would reduce their risk exposure by reducing the volume of exports. These findings have important policy implications. Market intervention to stimulate exports may fail if the authorities ignore the effects of exchange rate volatility. We argue that stable exchange rate is needed to enhance South Africa's international competitiveness and greater penetration of its exports to international markets. The South African monetary authority (SARB) will need to implement policies that would reduce exchange rate volatility such as the use of capital control techniques, since the current neoliberal strategy appear to have contributed to the increasing portfolio flows and hence exchange rate volatility in South Africa (Marcus, 2012; Institute of International Finance, 2014). SARB should also avoid policy statements which may encourage negative sentiments towards domestic financial market by foreign investors. Although, we cannot deny the benefits of a flexible exchange rate, we argue that a relative stable exchange rate would reduce inflation and subsequently increase exports and reduce uncertainty in the entire real sector of South African economy.

Further, given the existence of asymmetry, the role of the exchange rate in determining export revenue may prove less predictable. This holds implications for both investors and policy makers alike. Investors should consider the asymmetric risk and hence asymmetric 
benefit-loss structures of investment assets when developing their investment and risk management strategies. The existence of asymmetric exchange volatility effects complicates and increases the uncertainty of trade policy. Therefore, a full understanding and control of exchange volatility during periods of depreciation and appreciation is required for successful trade policy implementations.

\section{Conclusion}

Our paper tests the impact of exchange rate uncertainty on exports in South Africa by incorporating GARCH-in-mean errors in a structural Vector Auto Regression model following Elder (1995 and2004) and Elder and Serletis (2010). We use South Africa's quarterly REER and aggregate exports data covering the period 1986Q4-2013Q2. We measure exchange rate uncertainty by the standard deviation of the one-step-ahead forecast error of the growth rate of REER, conditional on the contemporaneous information set. Empirical results from our research suggested that exchange rate uncertainty significantly weighs down exports in South Africa for the period under review. Our results concur with results found by Rahman and Serletis (2009) who used the same methodology for US data.

Our results offer some support for the belief that exchange rate uncertainty leads to deterioration in the dynamic response of real exports to a positive exchange rate shock, while the dynamic response of real exports to a negative shock is negative but not significant. Our results also show that the responses of exports to positive and negative exchange rate shocks of equal magnitude are asymmetric as indicated by a larger response to a positive shock.

The dynamic responses of exports from a negative shock on exchange rate uncertainty found in our study have important policy implications for South African authorities. Our research results support the view that the SARB should consider implementing policy actions such as the use of capital control techniques as against the current laissez-faire management which could have contributed to the volatility of the rand. This is particularly important since 
exchange-rate risk can increase transaction costs and reduce gains to international trade thereby affecting the real economy through its effect on consumption and investment decisions. Given the existence of asymmetry, investors should consider the asymmetric risk and hence asymmetric benefit-loss structures of investment assets when developing their investment and risk management strategies. More so, a full understanding and control of exchange volatility during periods of depreciation and appreciation is required for successful trade policy implementations. 


\section{References}

Asseery, A and DA Peel (1991). The effects of exchange rate volatility on exports. Economics Letters, 37, 173-77.

Bae, SC and TH Kwon (2013). Managing asymmetric foreign exchange exposure with financial derivatives: evidence from Korean firms. In Proc. Academic and Business Research Institute, Las Vegas, October 10 - 12, 2013.

http://www.aabri.com/LV2013Manuscripts/LV13093.pdf [Accessed 20 November 2013].

Bird, G and RS Rajan (2001). International currency taxation and exchange rate stabilisation in developing countries? Journal of Development Studies, 37, 21-38.

Bredin, D, J Elder and S Fountas (2010). Oil volatility and the option value of waiting: An analysis of the G-7. Journal of Futures Markets, 31, 679-702.

Bernanke, BS (1986). Alternative Explanations of the Money-Income Correlation, CarnegieRochester Conference Series on Public Policy, 25, 49-99.

Bollerslev, T, RF Engle, and DB Nelson (1994). ARCH models. In Handbook of Econometrics, RF Engle and DL McFadden (Eds.), pp. 2959- 3038.

Bollerslev, T (1986). Generalized autoregressive conditional heteroskedasticity. Journal of Econometrics, 31, 307-27.

Caballero, RJ and V Corbo(1989). The effect of real exchange rate uncertainty on exports: Empirical evidence, The World Bank Economic Review 3, 263-278.

Clark, PB (1973). Uncertainty, exchange risk and the level of international trade. Western Economic Journal, 11, 302-313.

Clark, P, N TamirisiaSJ WeiA Sadikovand L Zeng (2004). Exchange rate volatility and trade flows: some new evidence, IMF Occasional Paper .https://www.imf.org/external/np/res/exrate/2004/eng/051904.pdf [Accessed 20 November 2013]

Cote', A (1994). Exchange rate volatility and trade: a survey, Bank of Canada Working Paper 94-5.http://www.bankofcanada.ca/1994/05/working-paper-1994-5/ [Accessed 25 November 2013]

De Arcangelis, G and C Pensa (1997). Exchange rate volatility, exchange rate pass-through and international trade: some new evidence from Italian export data. http://citeseerx.ist.psu.edu/viewdoc/download;jsessionid=0A7CBC6AB0DE675DD0B1EE4C ED05705F?doi=10.1.1.26.8962\&rep=rep1\&type=pdf [Accessed 20 November 2013].

Elder, J (1995). Macroeconomic and financial effects of monetary policy and monetary policy uncertainty. Unpublished doctoral dissertation, Department of EconomicsUniversity of Virginia. 
Elder, J (2004). Another perspective on the effects of inflation volatility. Journal of Money, Credit, and Banking, 36, 911-28.

Elder, J and A Serletis (2010). Oil price uncertainty. Journal of Money Credit and Banking, 42, $1137-1159$.

Engle, RF (1982). Autoregressive conditional heteroskedasticity with estimates of the variance of UK inflation. Econometrica, 50, 987-1008.

Engle, RF and V Ng (1993). Measuring and testing the impact of news on volatility. Journal of Finance, 48, 1749-1778.

Engle, RF and KF Kroner (1995). Multivariate simultaneous generalized ARCH. Econometric Theory, 11, 122-150.

Ethier, W (1973). International trade and forward exchange market. American Economic Review, 63, 494-503.

Fang, W, Y Lai and SM Miller (2009). Does exchange rate risk affect exports asymmetrically? Asian evidence. Journal of International Money and Finance, 28, 215-239.

Franke, G (1991). Exchange rate volatility and international trading strategy. Journal of International Money and Finance, 10, 292-307.

Fuchs, M and A Torchia (2011). South African volatility hurting the rand. Mail and Guardian Business Africa, 13 November 2011

Gross, J and D Maylie (2011). Debate over value of rand. The Wall Street Journal Online, 13 August 2011, http://online.wsj.com/news/articles/SB10001424053111904823804576504552432496970 [Accessed 25 January 2014]

Hamilton, JD (1994). Time Series Analysis. Princeton University Press, Princeton, NJ. Hansen, PR and A Lunde (2005). A forecast comparison of volatility models: Does anything beat a GARCH $(1,1)$ ? Journal of Applied Econometrics, 20, 873-889.

Héricourt J and S Poncet (2012). Exchange rate volatility, financial constraints and trade: empirical evidence from Chinese firms, CEPII Discussion Paper 2012-35, December.

Héricourt, J and S Poncet (2013). Exchange-rate volatility is a problem for trade especially when financial development is low. http://www.voxeu.org/article/when-exchange-ratevolatility-affects-trade.

Hodge, D. (2005). The effect of exchange rate volatility on trade and employment: A brief review of the literature, Human Sciences Research Council.http://www.hsrc.ac.za/en/researchdata/view/2770 [Accessed 25 November 2013]

Institute of International Finance (2014). Capital flows to emerging market economies. IIF Research Note, January 30, 2014. 
Isa, M (2009). Patel says rand debate will weigh costs, benefits in complex trade-off, BDlive, www.dblive.co.za/articles/2009/12/04 patel-says-rand-debate-will-weigh-costs-benefits-incomplex-trade-off [Accessed 20 January 2014]

Kroner, KF and WD Lastrapes (1993). The impact of exchange rate volatility on international trade: Reduced form estimates using the GARCH-in-Mean model. Journal of International Money and Finance, 12, 298-318.

Lee, K S Ni and R Ratti (1995). Oil shocks and the macroeconomy: The role of price variability. Energy Journal, 16, 39-56.

Luus, C (2010). The Rand: To peg or not to peg. The South African Financial Markets Journal, $11^{\text {th }}$ edition, April 2010

Marcus, G. 2012. Challenges to South African monetary policy in a world of volatile capital flows. A speech by Governor of the South African Reserve Bank To the Swiss Chamber Southern Africa, Zurich, 7 May 2012.

McGroarty, P (2013). South Africa's rand too volatile for factories to benefit, The Wall Street Journal Online, 5 September 2013, www://online.wsj.com/news/articles/SB1000142412788732 [Accessed 20 January 2014]

McKenzie, MD (1999). Impact of exchange rate volatility on trade flows, Journal of Economic Surveys, 13, 71-106.

Nyahokwe, O and R Ncwadi (2013). The impact of exchange rate volatility on South African exports, Mediterranean Journal of Social Science, 4(3), 507-513.

Ozturk, I., (2006). Exchange rate volatility and trade: A literature survey. International Journal of Applied Econometrics and Quantitative Studies, 3(1), 85-102.

Pagan, A (1994). Econometric issues in the analysis of regressions with generated regressors. International Economic Review, 25, 221-247.

Pétursson, TG (2009). Does inflation targeting lead to excessive exchange rate volatility? Central Bank of Iceland, Working Paper No. 46.

http://www.sedlabanki.is/lisalib/getfile.aspx ?itemid=7333.

Rahman, S and A Serletis (2009). The effects of exchange rate uncertainty on exports. Journal of Macroeconomics, 31, 500-507.

Rajan, RS (2004). Choosing an appropriate exchange rate regime for small and open emerging economies. Briefing Notes in Economics. http://ramkishenrajan.gmu.edu/pdfs/publications/Published_Academic_Papers/2004/bnerajan.pdf [Accessed 1 February 2014]

Rajan, RS( 2002). Exchange rate policy options for post-crisis southeast asia: is there a case for currency baskets? The World Economy, 25, 137-163.

Schaling, E., 2007. Reducing exchange rate volatility and supporting competitiveness. Trade and Industry Policy Strategies, South Africa, Annual Forum 2008. 
http://www.tips.org.za/publication/reducing-exchange-rate-volatility-and-supportingcompetitiveness [Accessed 10 November 2013]

Sekantsi, L (2011). The impact of real exchange rate volatility on South African exports to the United States: A bounds test approach. Review of Economics and Business Studies, 4(2), 119-139.

Sims, CA (1980). Macroeconomics and reality. Econometrica, 48, 1-48.

South African Reserve Bank (2013). Monetary Policy Statement September 2013. https://www.resbank.co.za/Lists/News\%20and\%20Publications/Attachments/5910/MPC\%20 Statement\%20September\%20\%202013\%20Final.pdf [Accessed 15 January 2014]

Taylor, SJ (1987). Forecasting the volatility of currency exchange rates. International Journal of Forecasting, 3, 159- 170.

Todani, RK and T Munyama (2005). Exchange rate volatility and exports in South Africa. http://www.tips.org.za/files/773.pdf [Accessed 12 October 2013].

Van der Merwe, EJ (1996). Exchange rate management policies in South Africa: Recent experience and prospects. South African Reserve Bank Occasional Paper No. 9.

Viaene, JM and CG de Vries (1992). International trade and exchange rate volatility. European Economic Review, 36, 1311-1321.

Wesseh , PK and L Niu (2012). The impact of exchange rate volatility on trade flows: new evidence from South Africa. International Review of Business Research Papers, 8(1), 140-165.

Zakaria, Z (2013). The relationship between export and exchange rate volatility: Empirical evidence based on the trade between Malaysia and its major trading partners. Journal of Emerging Issues in Economics, Finance and Banking, 2, 668-684.

Table 1: Model specification tests 


\begin{tabular}{|l|l|c|}
\hline \multirow{2}{*}{ Bivariate Model } & \multicolumn{3}{|l|}{ Schwarz Criterion Value } \\
\cline { 2 - 3 } & VAR & GARCH-in-Mean VAR \\
\hline Real exports and real effective exchange rate & 995 & 980 \\
\hline
\end{tabular}

Table 2: Coefficient estimates for the variance function of the GARCH-in-Mean VAR

\begin{tabular}{|l|c|c|c|c|}
\hline & $\begin{array}{l}\text { Conditional } \\
\text { Variance }\end{array}$ & Constant & $\varepsilon_{\mathrm{j}}(\mathrm{t}-1)^{2}$ & $\mathrm{H}_{\mathrm{j}}(\mathrm{t}-1)$ \\
\hline REER Equation & $\mathrm{H}_{\text {reer }}(\mathrm{t})$ & 1.1 & 0.92 & 0.0 \\
& & $(3.51)$ & $(10.97)$ & \\
\hline Exports Equation & $\mathrm{H}_{\exp }(\mathrm{t})$ & 0.48 & 0.45 & 0.51 \\
& & $(1.07)$ & $(2.53)$ & $(2.92)$ \\
\hline
\end{tabular}

Note: These are the constants and parameter estimates of $F_{1}, F_{2}, G_{1}$ and $G_{2}$ in the system of equations shown in (3) with $\varepsilon_{\mathrm{t}} \| \Pi_{\mathrm{t}-1} \sim \mathrm{iid}\left(0, \mathrm{H}_{\mathrm{t}}\right)$.Asymptotic t-statistics are in parentheses. 
Figure 1: Quarterly real effective exchange rate growth rate

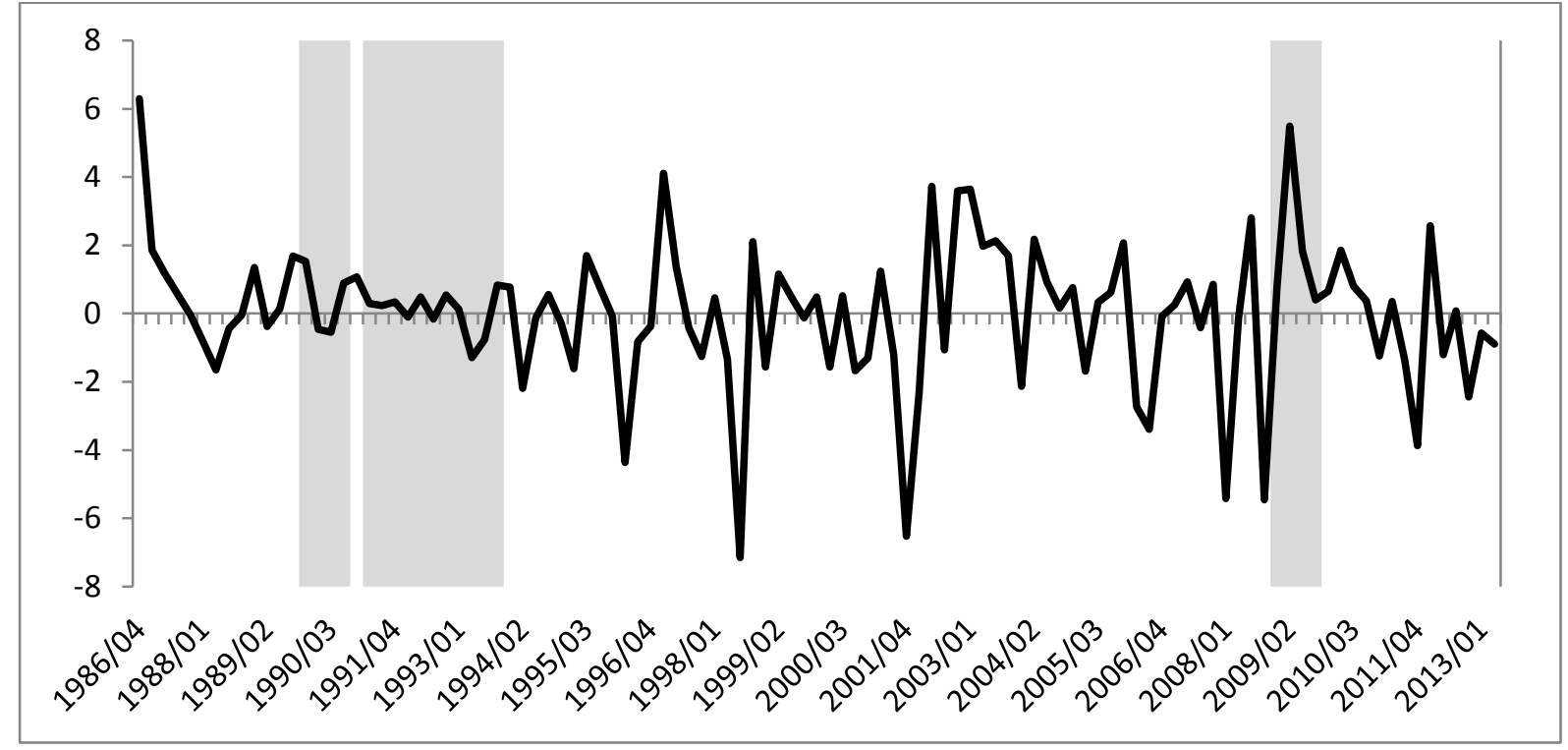

Note: The shaded areas on the graphs represents recession periods in South Africa

Figure 2: Quarterly South African exports growth rate

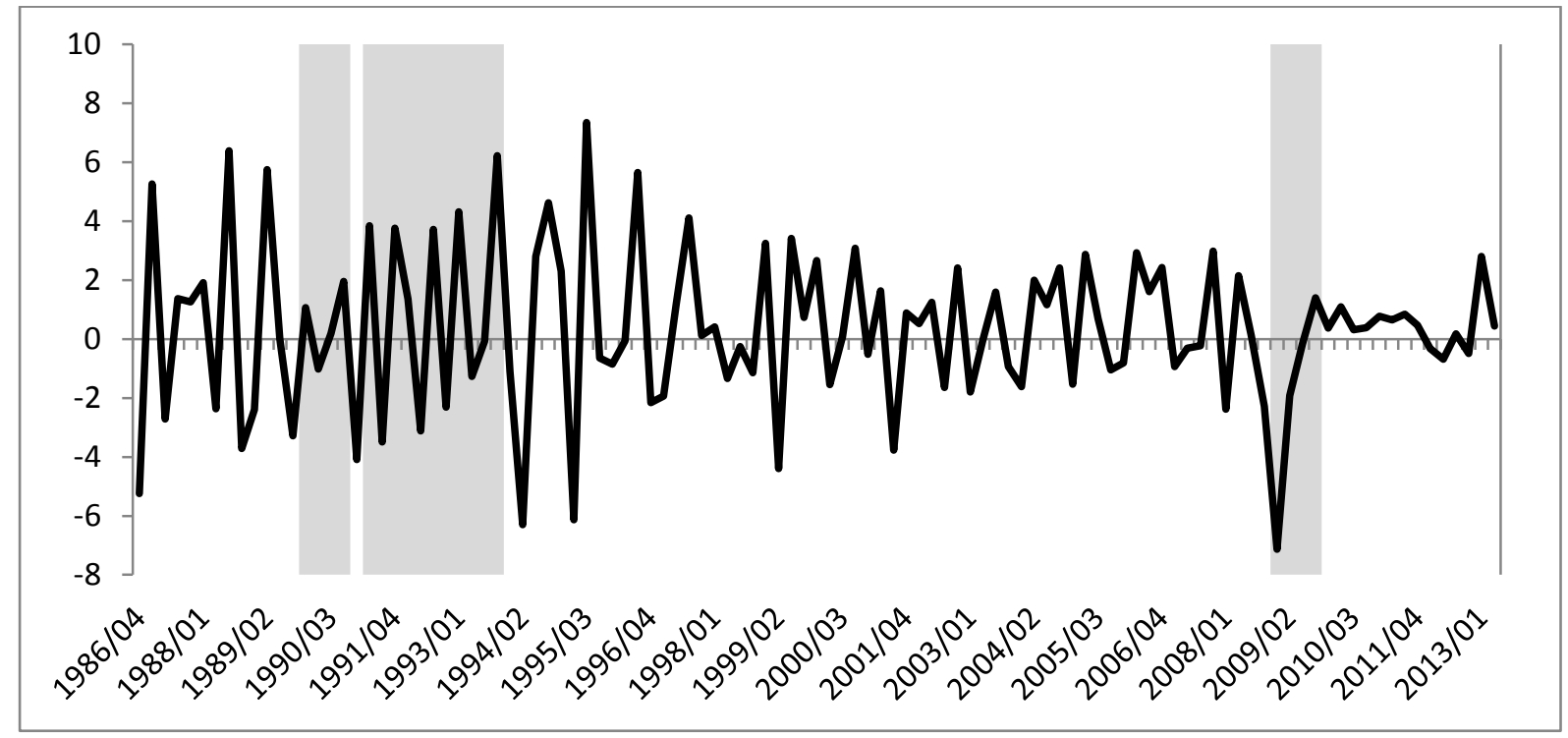

Note: The shaded areas on the graphs represents recession periods in South Africa.

Figure 3: Response of exports to positive and negative real effective exchange rate shocks 


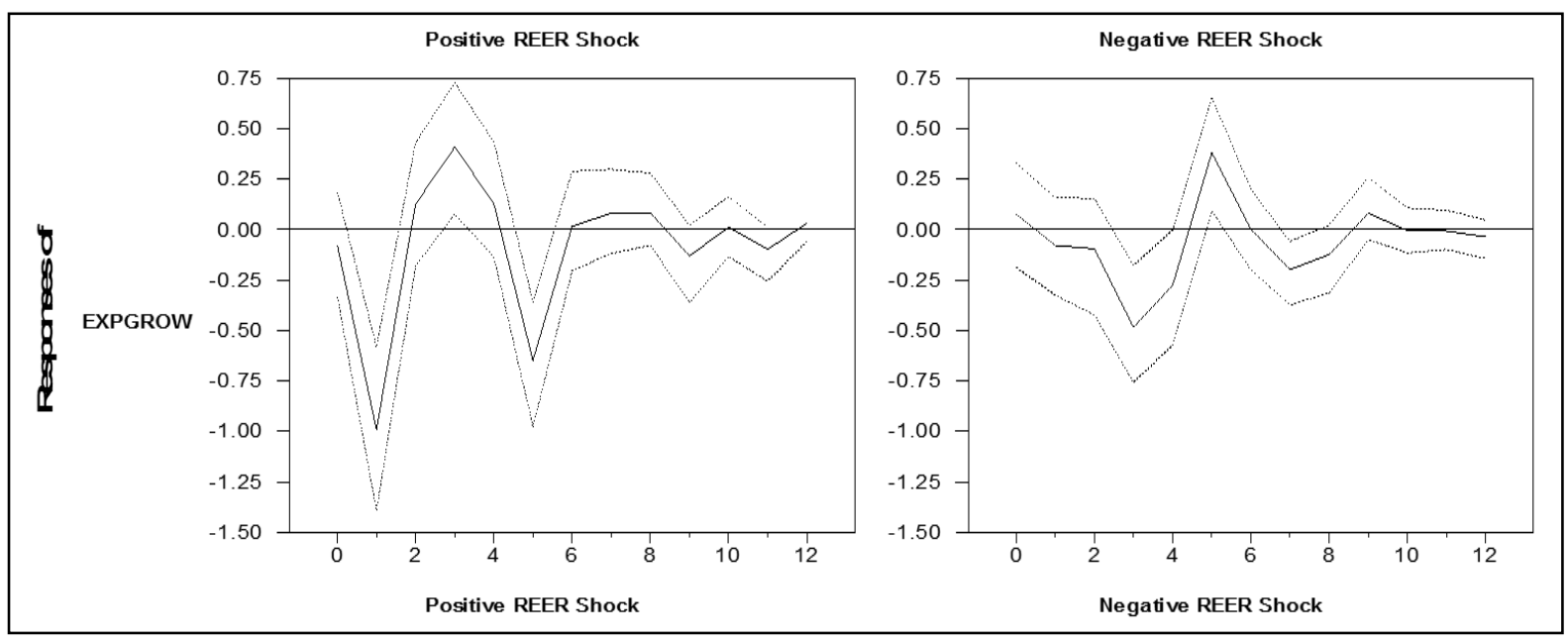

Figure 4: Responses exports to exchange rate shocks with and without the in-mean effect

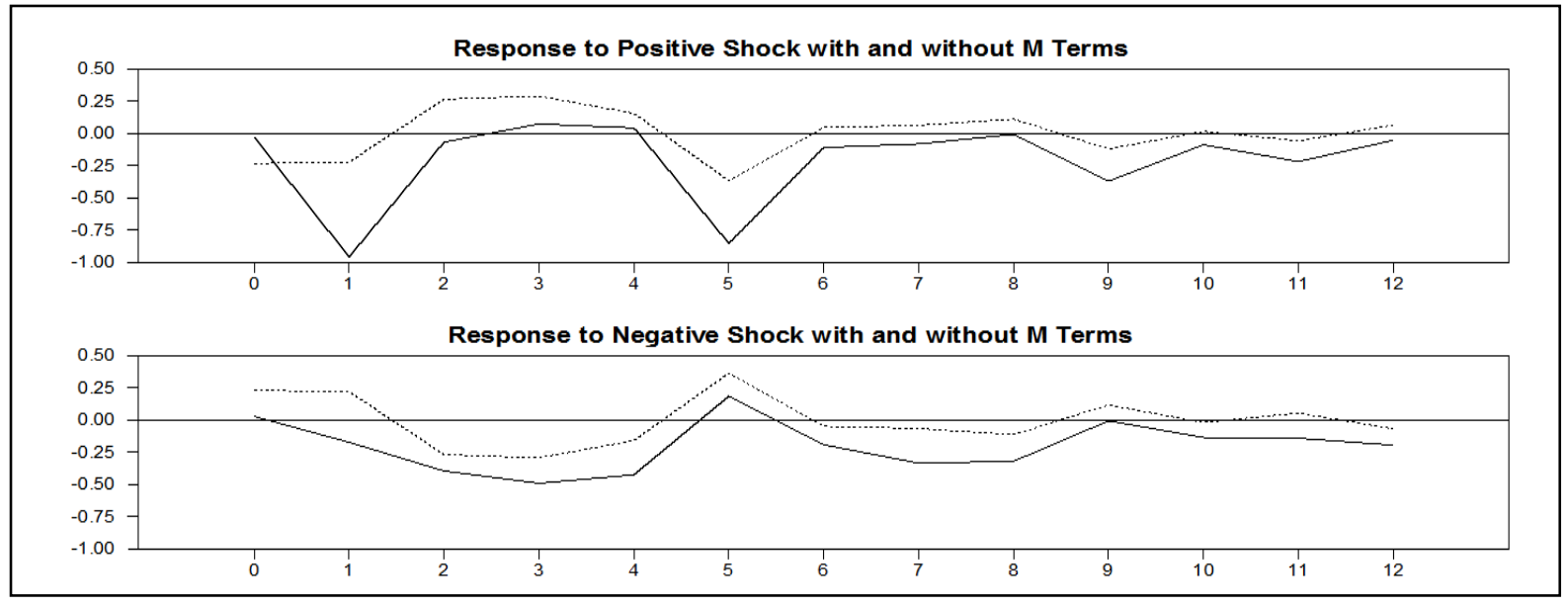

Note: The solid lines represent the response of exports following an effective exchange rate shock after allowing the exchange rate uncertainty into the export equation. The dotted lines represent the response of exports following an effective exchange rate shock without allowing the exchange rate uncertainty into the export equation. 